\title{
Comparison of the Vegetables Farming System as the Best Model in Kaimana - Indonesia
}

\author{
Obadja Andris, Dwidjono H.D.
}

Agricultural Economic Department of Agriculture Faculty,

Gadjah Mada University

obandris@gmail.com

\begin{abstract}
Development, including agricultural development anywhere is always clashing traditional society to modern society. Both of these social groups have different views in a production orientation, perspective to the technology used. Proponents of progress, make the laws of the market as a fundamental reason why productivity should be encouraged to meet the needs of population. Environmental degradation in recent years, give signals for the need of production systems that are environmentally friendly and healthy. Using descriptive methods, this research proves that the traditional farming systems is still existent, efficient and healthy for organic products, and the most importants is environmentally friendly, so it should be considered to be a model farming with a few modification to increase the farmers income.
\end{abstract}

Keywords: traditional farmer, intensive farmer, subsistence, vegetables

\section{INTRODUCTION}

Until the end of 2000, the agricultural system in the West region of New Guinea still had not moved from the traditional pattern with a mix of farming patterns. The pattern does not emphasize on the productivity as the ultimate goal of production activities. The production activity is still limited to basic needs, so this form of the social structure is also too simple. The community depends on the environment and the seasons change, so there is no livelihoods as real farmers in Papua. The farmers are also as hunters, fishermen and artisans.

The natural population growth plus the flow of migrants who came to Papua on a large scale, especially in the beginning of 2001 have an impact on the need for more food (BPS, 2002). In 2001 was marked the year of regulatory changes in Indonesia, with the enactment of the Papua Special Autonomy Law (No. 21 of 2001) which has an impact on the size of the budgets of development so it attract people outside the island to come to West Papua.

The changes of the population composition confronts the local governments on the demand for agricultural products including vegetables in larger quantities than before. These challenges need a wise attitude in the middle of the issue of environmental degradation, especially global climate heats up. Thus, it is needed an agricultural development model that is able to meet the food needs of the population in sufficient quantity and quality, without sacrifice the environment.

The influx of immigrants clearly changed the social structure, as well as the composition of livelihoods, including farming systems. Kaimana Regency as the Capital District in the southern region of West Papua Province, being the size of the influence of migrants on the commodity of vegetable farming systems in particular. This study, comparing two communities that develop different farming systems, namely the traditional farming community and modern farming community. Traditional farmers use a mix of farming patterns, while intensive farmers monoculture farming patterns. This small laboratory could be a recommendaed agricultural model that is efficient, cheap, low risk, build food security, environment-friendly and bring prosperity to the community. Should a subsistence agriculture was maintained by giving special treatment (Clements et al., 2014), or was allowed to follow the market mechanism to compete with a modern agriculture which is more motivated by the spirit of the green revolution. Finally, there are only four critical success factors of an agricultural development policy in reducing poverty, namely agriculture that answers the needs of the household, local participation and adaptation of development in accordance with the local situation (Dawson et al., 2016). 


\section{Materials AND Methods}

Different farming systems in every place in accordance with the development of social and environmental conditions (Foran et al, 2004; Rurinda et al., 2014). This study uses cluster sampling method (have now, 2006) so that the sample taken is already differentiated according to population. The research sample focused on vegetable farming community with mixed patterns and monoculture in District Kaimana. Types of vegetables observations were limited to three main commodities, namely vegetable kale, tomatoes and beans.

Regarding the number of samples, Nasution (2008) describes the rule that 10 percent of the population is considered sufficient, so that the total number of 180 farmers from 330 farmers (BPS, 2015) was more than adequate. The amount is well adapted to the Ochiri Yumane (2015) formula that is

$$
n=\frac{N}{1+N(e)^{2}}
$$

Where $\mathrm{n}=$ the number of samples, $\mathrm{N}=$ the total population size, and $\mathrm{e}=1-$ Confidence level (the margin of error).

The Location of study limited to the territory of Kaimana district administration in West Papua, Indonesia. The district selected due to its status as the capital of Kaimana district, as the area farthest from West Papua Province. The district is adjacent to the multinational companies Feeport McMooran Cooper \& Gold Inc. in the South and British Petroleum Tangguh LNG at Northwestern.

\section{ReSult AND CONCLUSIONS}

The vegetables in this study limited to 3 main types of vegetables are kale, tomatoes and beans. These three vegetables are chosen for their production data is high and the most preferred by consumers and farmers. The population can be viewed as consumers of vegetables production. The estimates of Kaimana District residents in 2015 amounted to 33,078 people (CBS, 2015). The differences in production between traditional farmers and farmers will be the focus of intensive study as shown in Table 1.

Table 1. Overview of the two case vegetable farmers characteristic

\begin{tabular}{|c|c|c|c|c|}
\hline \multirow{2}{*}{ Indicators } & \multicolumn{2}{|c|}{ Traditional } & \multicolumn{2}{c|}{ Intensive } \\
\cline { 2 - 5 } & Mean & SD & Mean & SD \\
\hline Age of farmers (year) & 40.27 & 10.68 & 40.20 & 9.45 \\
\hline Formal education level (year) & 1.87 & 1.04 & 1.23 & 0.57 \\
\hline Number of family members (peoples) & 5.03 & 2.06 & 3.77 & 1.17 \\
\hline Numer of productive family members (peoples) & 2.67 & 1.35 & 2.57 & 0.77 \\
\hline Farming experience (year) & 8.23 & 6.98 & 10.20 & 5.52 \\
\hline
\end{tabular}

The most fundamental difference between the two communities are the number of family members and farming experience. The average traditional farmers in a single household unit is consist of five members, while the intensive farmer is 4 people. Also, the average intensive farming experience for the farmers are longer than the traditional farmers.

\subsection{Cropping System}

Vegetable production as well as the cultivation of other crops, is determined by environmental factors such as climate, soil conditions and water availability. Kaimana is tropical humid climate regions where is very wet (Type A) according to the classification of Mohr and Schmidt-Ferguson. By looking at the data of rainfall per year in Kaimana that reaches 2,313 $\mathrm{mm}$ with the number of rainy 214 days, then it can be considered adequate water available throughout the year. An average minimum temperature of $24.1{ }^{\circ} \mathrm{C}$ per month with a humidity of $83.8 \%$ per month and the intensity of solar radiation $45.8 \%$ per year (CBS, 2015). The suitable climate for horticulture vegetables.

The traditional farmers are people from the local tribes. They use a system of shifting cultivation with annual cycles before returning to their first garden in the 5th year. Tubers become the major crops, interspersed with perennials as a marker of land ownership and vegetables for their own consumption. Vegetables are planted irregularly within a stretch of land bordering the garden. 
Intensive farmers come from other tribes who come from outside the island of Papua. They were mostly from Java, Sulawesi and Madura. The intensive farmers have already used a variety of means of production, the lands that are used by the imigrants are borrowed from the locals by an agreement that the migrants will plant and care the planted fruits tress such durian, rambutan, mango and so to fruition and after harvesting they will return the land to its owner. Modern farmers cultivate their land with short-term crops, especially various types of vegetables with monoculture indicated by a regular spacing.

\subsection{Use of Factors of Production}

Three types of vegetables in this study were observed according to existing farming systems in Kaimana. Since the beginning distinguished between intensive farming systems with traditional farming systems, including the factors of production as shown in Table 2.

Table 2. Production inputs on vegetables cultivation system per year

\begin{tabular}{|c|c|c|c|c|}
\hline \multirow{2}{*}{ Variables } & \multicolumn{2}{|c|}{ Traditional } & \multicolumn{2}{c|}{ Intensive } \\
\cline { 2 - 5 } & Mean & SD & Mean & SD \\
\hline Harvested Area (ha) & 0.68 & 0.14 & 0.77 & 0.35 \\
\hline Total Seed (kg) & - & - & 0.01 & 0.00 \\
\hline Total Fertilizer (kg) & - & - & 0.84 & 0.37 \\
\hline Pesticides (kg) & - & - & 1.24 & 0.47 \\
\hline Amount of fuel (liter) & 1.89 & 0.97 & 17.74 & 8.10 \\
\hline Outpouring of labor outside the household (mhw) & 171.77 & 83.68 & 161.87 & 72.14 \\
\hline The outpouring of labor in the household (mhw) & 660.629 & 210.55 & 439.09 & 162.69 \\
\hline
\end{tabular}

Explanation: $\mathrm{mhw}=$ man hours of work

The above table shows the differences between the farmers how to grow crops intensively with traditional farmers. Farmers intensive use of all factors of production well, while traditional farmers limited to land, fuel for transport and labor. The traditional farmers use labors from outside of their family only once when they clean up their lands. Other production phases such as planting, weeding, harvesting and post-harvest, are not using labor from outside the family. Instead of intensive farming systems use non-family labor (wage) throughout the growing season. The different workers indicate different social institutional system in both groups of farmers, and not solely for the purpose of efficiency alone (Doss \& Dick, 2015).

\subsection{The Analysis of Income}

Income is the difference between revenue and cost. Receipts derived from farming activities (on farm), agricultural processing activities (off farm) as well as the activities that have nothing to do with the activity of agriculture (non-farm). Table 3 will show the difference in the average production intensive farmers greater than traditional farmers. The differences are based on the motifs of production.

Table 3. Average Vegetables Production and Income per Planting Season

\begin{tabular}{|c|c|c|c|}
\hline \multirow{2}{*}{ Attribute } & $\begin{array}{c}\text { Trditional } \\
\text { Farmers }\end{array}$ & $\begin{array}{c}\text { Intensive } \\
\text { Farmers }\end{array}$ & Total \\
\cline { 2 - 4 } & $\mathbf{( n = 9 0 )}$ & $\mathbf{( n = 9 0 )}$ & $\mathbf{( n = 1 8 0 )}$ \\
\hline I. Farm Production (kg/year) & & & \\
\hline a. Vegetables & 176.70 & 439.43 & 308.07 \\
\hline 1). On sale & 116.57 & 377.83 & 247.20 \\
\hline 2). Consumed & 60.13 & 61.60 & 60.87 \\
\hline b. Non Vegetables (crops) & 180.20 & 130.43 & 155.32 \\
\hline 1). On sale & 99.77 & 84.97 & 92.37 \\
\hline 2). Consumed & 80.43 & 45.47 & 62.95 \\
\hline II. Product Price (IDR/ kg) & & & \\
\hline a. Vegetables & $13,000.00$ & $13,000.00$ & $13,000.00$ \\
\hline b. Non Vegetables (crops) & $3,333.33$ & $3,333.33$ & $3,333.33$ \\
\hline III. Revenue (IDR/year) & $4,229,683$ & $8,168,250$ & $6,198,967$ \\
\hline a. On Farm Revenue & $2,725,200$ & $7,129,583$ & $4,927,392$ \\
\hline 1). Cash Revenue & $1,767,383$ & $6,090,917$ & $3,929,150$ \\
\hline
\end{tabular}


Obadja Andris \& Dwidjono H.D.

\begin{tabular}{|c|c|c|c|}
\hline 1.1). Vegetables & $1,444,800$ & $5,722,000$ & $3,583,400$ \\
\hline 1.2). Non Vegetables & 322,583 & 368,917 & 345,750 \\
\hline 2). Non-Cash Revenue & 957,817 & $1,038,667$ & 998,242 \\
\hline 2.1). Vegetables & 702,733 & 849,500 & 776,117 \\
\hline 2.2). Non Vegetables & 255,083 & 189,167 & 222,125 \\
\hline 3). Vegetables Revenue & $2.147,533$ & $6,571,500$ & $4,359,517$ \\
\hline 4). Non-Vegetables Revenue & 547,833 & 450,917 & 499,375 \\
\hline b. Off Farm Revenue & $103,333.33$ & - & 51,667 \\
\hline c. Non Farm Revenue & 443,333 & - & 221,667 \\
\hline IV. Production Costs (IDR/year) & 320,660 & $2,507,175$ & $1,413,918$ \\
\hline 1). Fixed costs (depreciation tool) & 18,827 & 59,623 & 39,225 \\
\hline 2). Variable Cost & 150,917 & $2,169,518$ & $1,160,218$ \\
\hline V. Consumption Cost (IDR/year) & 894,020 & 889,907 & 891,963 \\
\hline VI. Income (IDR/year) & $2,057,186$ & $3,732,502$ & $2,894,844$ \\
\hline 1). Cash & $1,099,370$ & $2,693,835$ & $1,896,602$ \\
\hline 2). Non Cash & 957,817 & $1,038,667$ & 998,242 \\
\hline
\end{tabular}

The fact the differences between the two farmers communities could also be understood in the percentage of production that is consumed. Farmers consume less intensive than the production of traditional farmers for a more commercial orientation. Thus, the success of the production activity is highly dependent on human resources policies and farmers themselves (Rasmussen et al., 2016).

All activities both on-farm, off-farm and non-farm income is measured from each farmer. The average income of intensive farmers is higher than for traditional farmers. Despite higher earnings, more intensive farmers at risk in trying because it depends on factors of production coming from the factory. Meanwhile, total income for the farming both cash and non-cash income does not differ much, respectively IDR 2,057,186 for traditional farmers and IDR 3,732,502 for intensive farmers. Half (53.44\%) of the traditional farmer's income is the income in cash and the remainder in the form of non-cash income, otherwise the majority $(72.17 \%)$ of cash income is cash income of farmers intensively and the remaining non-cash income.

Structurally, the income analysis which compares both of the farmers group in Kaimana, from side of efficiency, risk, self-reliance and sustainability, it shows that the system of traditional farming is more excellent than the intensive farmers. The farming system, successfully regenerate the soil and the forest environment is proportional to Munder et al. (2014).

\section{REFERENCE}

[1] BPS, 2002. West Papua Province in Figures.

[2] Clement T., Suon S., Wilkie D.S., 2014. Impacts of Protected Areas on Local Livelihoods in Cambodia. World Development Vol. 64, pp. S125-S134, 2014.

[3] Dawson N., Martin A. \& Sikor T., 2016. Green Revolution in Sub-Saharan Africa: Implications of Imposed Innovation for the Wellbeing of Rural Smallholders. World Development Vol. 78, pp. 204-218, 2016.

[4] Foran T., Butler J.R.A., Williams L.J., Wanjura W.J., Hall A., Carter L. \& Carberry P.S., 2014. Taking Complexity in Food Systems Seriously: An Interdisciplinary Analysis. World Development Vol. 61, pp. 85-101.

[5] Rurinda J., Mapfumo P., van Wijk M.T., Mtambanengwe F., Rufino M.C., Chikowo R. \& Giller K.E., 2014. Sources of vulnerability to a variable and changing climate among smallholder households in Zimbabwe: A participatory analysis. Climate Risk Management 3 (2014) 65-78.

[6] Nasution M.E. \& Usman H., 2008. The process of Quantitative Research, $3^{\text {th }}$ edition. Issuing Faculty of Economics, University of Indonesia. Jakarta.

[7] BPS, 2015. Kaimana District in Figures.

[8] Ochiri, G., Wario G., Odhiambo R. \& Arasa R., 2015. Effects of Recycling Strategy on Firm Performance: A Survey of Publishing Firms in Kenya. International Journal of Research Studies in Agricultural Sciences (IJRSAS). Volume 1, Issue 1, May 2015, PP 1-10.

[9] Doss R.C. \& Dick R.M., 2015. Collective Action within the Household: Insights from Natural Resource Management. World Development Vol. 74, pp. 171-183. 
[10] Rasmussen L.V., Mertz O., Christensen A. E., Danielsen F., Dawson N., Xaydongvanh P., 2016. A combination of methods needed to assess the actual use of provisioning ecosystem services. Ecosystem Services17(2016)75-86.

[11] Munder S., Angelsen A. \& Belcher B., 2014. Forests, Livelihoods, and Conservation: Broadening the Empirical Base. World Development Vol. 64, pp. S1-S11.

\section{Authors' Profile}

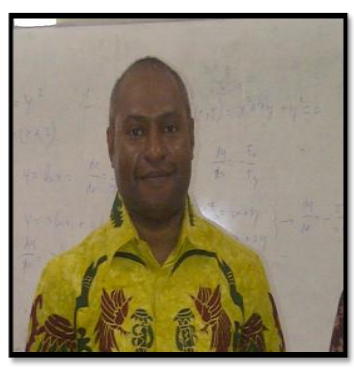

OBADJA ANDRIS, SP., M.Si., (Postgraduate Students at Agricultural Economy major, Agriculture Faculty, Gadjah Mada University)

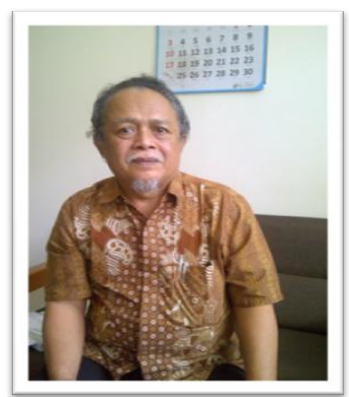

PROF. DWIDJONO HADI DARWANTO, MS, PhD., (Dissertation Promotor, Lecturer in Agricultural Economy Department of Agriculture Faculty, GadjahMada University) 